\title{
SURFACE FREE ENERGY OF HYDROPHOBIC COATINGS OF HYBRID-FIBER-REINFORCED HIGH-PERFORMANCE CONCRETE
}

\author{
PROSTA ENERGIJA POVRŠINE HIDROFOBNIH PREMAZOV NA \\ VISOKOZMOGLJIVEM BETONU, OJAČANEM S HIBRIDNIMI \\ VLAKNI
}

\author{
Danuta Barnat-Hunek, Piotr Smarzewski \\ Lublin University of Technology, Faculty of Civil Engineering and Architecture, Nadbystrzycka Str. 40, 20-618 Lublin, Poland \\ d.barnat-hunek@pollub.pl \\ Prejem rokopisa - received: 2014-08-03; sprejem za objavo - accepted for publication: 2014-12-12
}

doi: $10.17222 / \mathrm{mit} .2014 .174$

\begin{abstract}
The aim of the research presented in the paper was to evaluate the feasibility of using hydrophobic preparations based on organosilicon compounds for the protection treatment of hybrid-fiber-reinforced high-performance concrete (FRHPC) surfaces. The wettability of concrete has a direct effect on the durability and corrosion resistance. The wetting properties of FRHPC were evaluated through the measurement of the contact angle between the surfaces of these materials with either water or glycerine used as probe liquids. On this basis, the surface free energy (SFE) was determined. The polar and disperse components of SFE were obtained by means of the Owens-Wendt method. Three different siloxane preparations were deposited onto seven types of concrete with the fiber content ranging from $0 \%$ to $1 \%$. In order to investigate the effect on the strength, the granodiorite aggregate in concrete mixes 5, 6, 7 was replaced with granite. The basic characteristics of the concrete strength were examined: the tensile splitting strength, the compressive strength, the modulus of elasticity. A SEM examination of the coated concrete surfaces confirmed that preparations A-C can effectively cover the voids and pores present in the concrete surfaces. The presented results indicate that the surfaces of the concrete with a silane film had a wide range of SFE, depending on the kind of agent. SFE depended on the chemical reactivity of the silanes used, the type of solvent, the viscosity and surface tension of the solution. The evaluation of the contact angle and SFE helped to efficiently select the most appropriate preparation.

Keywords: surface free energy (SFE), contact angle, hydrophobization, high-performance concrete, hybrid fiber, Owens-Wendt method
\end{abstract}

Namen raziskave, predstavljene $\mathrm{v}$ članku, je bil oceniti izvedljivost uporabe hidrofobne obdelave na osnovi organosilikonskih spojin za zaščito površine zmogljivega betona (FRHPC), ojačanega s hibridnimi vlakni. Omočljivost betona ima neposreden vpliv na zdržljivost in odpornost proti koroziji. Omočljivost FRHPC je bila ocenjena z merjenjem stičnega kota med površino teh materialov pri uporabi vode in glicerina kot preizkusne tekočine. Na tej osnovi je bila določena prosta energija površine (SFE). Polarne in razpršilne komponente SFE so bile določene z Owen-Wendtovo metodo. Trije različni pripravki siloksana so bili naneseni na sedem vrst betona $\mathrm{z}$ vsebnostjo vlaken od $0 \%$ do $1 \%$. Za preiskavo vpliva na trdnost je bil zrnati granodiorit nadomeščen $\mathrm{v}$ betonskih mešanicah 5,6 in $7 \mathrm{z}$ granitom. Preiskovane so bile osnovne značilnosti trdnosti betona: natezna cepilna trdnost, tlačna trdnost in modul elastičnosti. SEM-preiskave pokrite površine betona so potrdile, da priprave A-C lahko učinkovito prekrijejo praznine in pore, ki so na površini betona. Prikazani rezultati kažejo, da ima površina betona s plastjo silanov velik razpon SFE, odvisno od vrste predstavnika. SFE je odvisna od kemijske reaktivnosti uporabljenega silana, vrste topila, viskoznosti in površinske napetosti raztopine. Ocena kota stika in SFE je pomagala pri izbiri najbolj primernega preparata.

Ključne besede: prosta energija površine (SFE), kot stika, hidrofobizacija, visokozmogljiv beton, hibridna vlakna, OwensWendt-ova metoda

\section{INTRODUCTION}

High-performance fiber-reinforced concrete is a cementitious material with a low water/cement ratio and a high cement content. ${ }^{1,2}$ Short, straight steel fibers are usually used to enhance the tensile strength and increase the ductility. As a result, the mechanical properties of hybrid-fiber-reinforced high-performance concrete are considerably enhanced compared to the normal concrete. ${ }^{2,3}$ High-performance concretes are often exposed to aggressive impacts of the environment and, therefore, they must have a high resistance to chemical corrosion, frost corrosion, weathering, impact of aggressive water and many other corrosive agents.
Moisture damage is a major factor in the deterioration of building materials. One of the methods used to protect the concrete surface is hydrophobization. ${ }^{4,5}$ It causes a decrease in the capillary water absorption, thus allowing free vapor permeability. Organosilicon compounds - siloxanes or methyl silicone resins ${ }^{6-8}-$ are mostly used as concrete hydrophobing agents. Research ${ }^{9}$ confirmed that a polyethylhydrosiloxane admixture has a beneficial effect on the durability of the concrete with large volumes of supplementary cementitious materials. Concrete is normally a hydrophilic material, which significantly reduces the durability of concrete structures. In the research to synthesize water-repellent concrete, the emulsion was enriched with the polymethyl-hydrogen 
siloxane-oil hydrophobic agent. ${ }^{10}$ There are also tests aimed at increasing the strength and toughness using special techniques like polymer impregnation of the matrices of fibre-reinforced concretes. ${ }^{11}$

Sustainability is the necessity for concrete and nanotechnology is the chance for the future of concrete-polymer composites. ${ }^{12}$ In the case of impregnation, polymercement concrete (PCC) gained popularity. The most often used polymer-cement concretes are modified using styrene-butadiene co-polymer, acrylic polymers and epoxy resin. ${ }^{13}$

These coatings make the concrete surface non-wettable by water and corrosive compounds such as watersoluble salts. The fact that building materials can be wetted by liquids is of special importance, for example, during their hydrophobization, impregnation and in the production of anti-graffiti agents. The wettability of concrete by means of liquids which contain corrosive components is of great importance in practice; it may indicate adhesive properties of concrete as well as protective coatings applied to its surface. The wettability of concretes has a direct effect on the durability and corrosion resistance. In the research of concretes, their wettability and surface free energy (SFE) are considered to be important elements in assessing the adhesion properties. They are particularly useful in the analysis of the effects of modifying the surfaces of high-strength concretes by means of various protective coatings.

According to the literature data, ${ }^{14-16}$ the contact angle of the materials is an indicator of their wettability properties. High wettability - hydrophilicity - occurs at a low contact angle $<90^{\circ}$, and insufficient wettability hydrophobicity - occurs at a high contact angle $>90^{\circ}$. The contact angle can be used to determine the surface tension $^{12}$ and define the surface free energy ${ }^{17-19}$ and adhesion operation. ${ }^{14,20,21}$

The contact angle is influenced by many factors which include, but are not limited to, the following: surface physical and chemical homogeneity, surface roughness and impurities, type of the measured liquid, drop size of the measured liquid, humidity or ambient temperature. ${ }^{18-21}$ Among the most commonly used methods for determining the contact angle, one can mention the following: the air-bubble method, the geometric method, the liquid-capillary-rise methods tested on sample materials (among others, the Wilhelmy method) and the direct-measurement method. ${ }^{22-25}$ A very popular method to measure the contact angle is direct measurement using a contact-angle analyzer or a goniometer. ${ }^{26,27}$

The surface free energy (the surface tension) is the key parameter while evaluating the physicochemical characteristics of solid surfaces. The surface may be of a dispersive nature (a dispersion component) or polar (a polar component). Knowing the properties of impregnating agents one can decrease or increase the SFE and, therefore, the surface tension of materials, causing their non-wettability, which is related, among others, to the chemical corrosion and frost resistance. The highest decrease in SFE can be due to the coatings that hydrophobize a surface to the largest extent. ${ }^{28}$

The surface free energy (SFE) is one of the thermodynamic quantities describing the state of equilibrium of the atoms in the surface layers of materials. ${ }^{14,29} \mathrm{SFE}$ represents the state of imbalance of the intermolecular interactions present at the phase boundary of two different mediums. There are numerous methods for direct determination of the surface free energy of liquids. Owing to the fact that there are no direct methods for determining the SFE of solids, some indirect methods are used, which include, among others, the contact-angle measurement method, calculating the surface free energy on the basis thereon. ${ }^{21,22,30}$

The main methods for determining SFE were formulated by Neumann, Wu, Owens and Wendt, Zisman and Fox, Fowkes, Van-Oss-Chaudhury-Good. ${ }^{21}$

The Owens-Wendt method is commonly used for determining the surface free energy of materials. ${ }^{19}$ This method consists of determining the dispersion and polar components of SFE. The polar component $\left(\gamma_{\mathrm{s}}^{\mathrm{p}}\right)$, which is the measure of the surface polarity, is associated with, among others, the bond strength between the materials.

The analysis of the nature of a hydrophobizedconcrete surface layer in terms of wettability presented in the article allowed us to assess, inter alia, the material behavior in the presence of water and corrosive compounds. In the cases where a significant resistance of a concrete surface layer to the impact of a corrosive environment is required, it is desirable to use preparations of the lowest SFE value.

\section{MATERIALS AND METHODS}

\subsection{Concrete mixtures}

In the laboratory, seven concrete mixtures were prepared using Portland cement $670.5 \mathrm{~kg} / \mathrm{m}^{3}$ (CEM I 52.5 N-HSR/NA), aggregate $990 \mathrm{~kg} / \mathrm{m}^{3}$, sand $500 \mathrm{~kg} / \mathrm{m}^{3}$, water $178 \mathrm{~L} / \mathrm{m}^{3}$, microsilica $74.5 \mathrm{~kg} / \mathrm{m}^{3}$, superplasticizer $20 \mathrm{~L} / \mathrm{m}^{3}$ and steel and polypropylene fibers in varied amounts.

Table 1: Fractions of fibers in various concretes

Tabela 1: Delež vlaken v različnih betonih

\begin{tabular}{|c|c|c|}
\hline \multirow{2}{*}{ Concrete type } & Fraction, \% \\
\cline { 2 - 3 } & Steel fibers & $\begin{array}{c}\text { Polypropylene } \\
\text { fibers }\end{array}$ \\
\hline \multicolumn{3}{|c|}{ granodiorite aggregate } \\
\hline HPC1 & - & - \\
\hline SFHPC & $1 \%$ & - \\
\hline HFHPC1 & $0.75 \%$ & $0.25 \%$ \\
\hline granite aggregate \\
\hline HFHPC2 & $0.5 \%$ & $0.5 \%$ \\
\hline HFHPC3 & $0.25 \%$ & $0.75 \%$ \\
\hline PFHPC & - & $1 \%$ \\
\hline HPC2 & - & - \\
\hline
\end{tabular}


Table 2: Mechanical properties of concretes

Tabela 2: Mehanske lastnosti betonov

\begin{tabular}{|c|c|c|c|c|c|c|c|}
\hline & HPC1 & SFHPC & HFHPC1 & HFHPC2 & HFHPC3 & PFHPC & $\mathrm{HPC} 2$ \\
\hline Compressive strength (MPa) & 151.0 & 154.9 & 144.7 & 133.9 & 122.3 & 94.6 & 129.5 \\
\hline Splitting tensile strength (MPa) & 8.9 & 13.8 & 13.5 & 10.0 & 9.3 & 7.6 & 6.8 \\
\hline Modulus of elasticity (GPa) & 38.37 & 39.74 & 34.27 & 32.45 & 29.60 & 29.42 & 32.55 \\
\hline
\end{tabular}

Table 1 lists abbreviated names of the concretes and amounts of steel and polypropylene fibers for various batches. Granodiorite aggregate was used for the first three concretes and granite aggregate was used for the remaining four concretes.

The concrete samples were made on the basis of a recipe determined experimentally using the known mortar according to EN 206:2014-04. The mixing procedure was as follows: quartz sand and coarse aggregate were homogenized together and mixed with half quantity of water. Then, cement, silica fume and the remaining water were added and, finally, superplasticizer was added. After the components were thoroughly mixed, fibers were gradually added by hand to obtain homogeneous and workable mixtures. The fibers were dosed gradually so as not to be tried and not to sink to the bottom of the mixture. The samples were formed directly after the concrete compounds were mixed according to EN 12390-2:2011.

Molds coated with an anti-adhesive substance were filled with concrete batches and compacted on a vibrating table. All the samples were stored at a temperature of about $23{ }^{\circ} \mathrm{C}$ until removing them from the moulds after $24 \mathrm{~h}$ and they were then placed in a water tank for 7 $\mathrm{d}$ to cure. After $7 \mathrm{~d}$ the samples were removed from the tank to cure in laboratory conditions for up to $28 \mathrm{~d}$.

\subsection{Properties of the concrete}

\subsubsection{Compressive strength and splitting tensile strength}

Cubic concrete samples with dimensions of $100 \mathrm{~mm}$ $\times 100 \mathrm{~mm} \times 100 \mathrm{~mm}$ were applied. Research was conducted according to EN 12390-3:2002 regarding the compressive strength and EN 12390-6:2001 regarding the splitting tensile strength. The evaluation of the grades of the concretes was carried out using a Walter-Baj AG compression tester within $3 \mathrm{MN}$ after $28 \mathrm{~d}$ of maturation, when the average compressive strength of the samples was obtained.

\subsubsection{Modulus of elasticity}

The determination of the modulus of elasticity was carried out on cylinders with a diameter of $150 \mathrm{~mm}$ and a height of $300 \mathrm{~mm}$ by measuring the deformation of the samples in a stress range from $0.5 \mathrm{MPa}$ to $30 \%$ of the concrete compressive strength. The examination was conducted by means of a Walter-Baj AG press and a modulus-measuring device with an extensometer.

The strength properties of the concretes adopted for the examination are shown in Table 2.

\subsection{Hydrophobic materials used}

Three hydrophobic preparations commonly used as construction chemicals were selected for the laboratory tests; they differed in the type of solvent, viscosity and concentration:

A - the water-based solution of methylosilicone resin in the potassium hydroxide $(1: 6)$,

B - the organic-solvent-based alkyl alkoxysilane oligomer,

$\mathrm{C}$ - the organic-solvent-based methylosilicone resin.

Each preparation was applied with a brush in two layers. The first preparation was diluted in the proportion of $1: 6$ according to the manufacturer's requirements. The other hydrophobic preparations with organic solvents were not diluted. Thereafter, all the hydrophobized bricks were seasoned for a period of $7 \mathrm{~d}$ in the laboratory conditions to control the process of hydrolytic polycondensation of the hydrophobic coatings.

Producers do not provide full product characteristics of the examined hydrophobic preparations or how their solutions are applied in practice. For that purpose the following parameters were determined experimentally: the viscosity factor and the surface tension for all the examined preparations. The major characteristics of the applied preparations used in the research are listed in the Table 3. Viscosity factor $\eta$ was determined by measuring the time of the solution flow in the Ostwald viscosimeter. The surface tension was measured by raising the fluid in the capillary. The research was executed at a room temperature of $22.5^{\circ} \mathrm{C}$.

Table 3: Basic characteristics of hydrophobic preparations Tabela 3: Osnovne značilnosti hidrofobnih preparatov

\begin{tabular}{|c|c|c|c|c|}
\hline $\begin{array}{l}\text { Type of } \\
\text { formu- } \\
\text { lation }\end{array}$ & $\begin{array}{c}\text { Viscosity } \\
\eta / \\
\left(\mathrm{Pa} \mathrm{s} \times 10^{-3}\right)\end{array}$ & $\begin{array}{c}\text { Density at } \\
20^{\circ} \mathrm{C} \\
\left(\mathrm{g} / \mathrm{cm}^{3}\right)\end{array}$ & $\begin{array}{c}\text { Surface } \\
\text { tension } \\
\sigma(\mathrm{N} / \\
\left(\mathrm{m} \times 10^{-3}\right)\end{array}$ & \begin{tabular}{|} 
Quotient of \\
surface \\
tension and \\
viscosity $\sigma / \eta$
\end{tabular} \\
\hline A & 1.099 & 1.26 & 67.92 & 61.73 \\
\hline B & 1.479 & 0.80 & 23.11 & 15.65 \\
\hline $\mathrm{C}$ & 2.846 & 0.82 & 24.30 & 8.54 \\
\hline
\end{tabular}

\subsection{Determination of the contact angle and surface free energy}

In order to calculate the surface free energy, the contact-angle measurements of the analyzed concretes were conducted. The method of directly measuring the angle formed by a drop of the measuring liquid with the surface measured was used, using a computer program for the image analysis. The measurement of the contact 
angles of the measuring-liquid drops was carried out on a research stand consisting of a goniometer integrated with a camera for taking photos of the drops put onto the surfaces of the samples. The stand was described in $^{31}$.

In order to examine the contact angle two measuring liquids were used - distilled water and glycerine required by the Owens-Wendt model used in the analyses. Measuring-liquid drops of $2 \mathrm{~mm}^{3}$ were deposited by means of a micropipette. ${ }^{14,32}$ Due to the heterogeneity of the material, six drops were put on each sample. The measurements were carried out twice: at the time of the application of the drops, i.e., at $0 \mathrm{~min}$ and at $40 \mathrm{~min}$. Standard and hydrophobized surfaces HFHPC1 during the examination of the contact angle of a glycerine drop are shown in Figure 1.

For the calculation of the wettability of the concrete surface, the SFE values of the measuring liquids $\left(\gamma_{\mathrm{L}}\right)$, and their dispersion $\left(\gamma_{\mathrm{L}}^{\mathrm{d}}\right)$ and polar components $\left(\gamma_{\mathrm{L}}^{\mathrm{p}}\right)$ were adopted as shown in Table $4 .^{33}$

Table 4: SFE values of measuring liquids, their dispersion and polar components ${ }^{33}$

Tabela 4: SFE-vrednosti izmerjenih tekočin in njihovih disperzijskih in polarnih komponent ${ }^{33}$

\begin{tabular}{|c|c|c|c|}
\hline \multirow{2}{*}{ Measuring liquid } & \multicolumn{3}{|c|}{ SFE and its components $\left(\mathrm{mJ} / \mathrm{m}^{2}\right)$} \\
\cline { 2 - 4 } & $\gamma_{\mathrm{L}}$ & $\gamma_{\mathrm{L}}{ }^{\mathrm{d}}$ & $\gamma_{\mathrm{L}}^{\mathrm{p}}$ \\
\hline Distilled water & 72.8 & 21.8 & 51.0 \\
\hline Glycerine & 62.7 & 21.2 & 41.5 \\
\hline
\end{tabular}
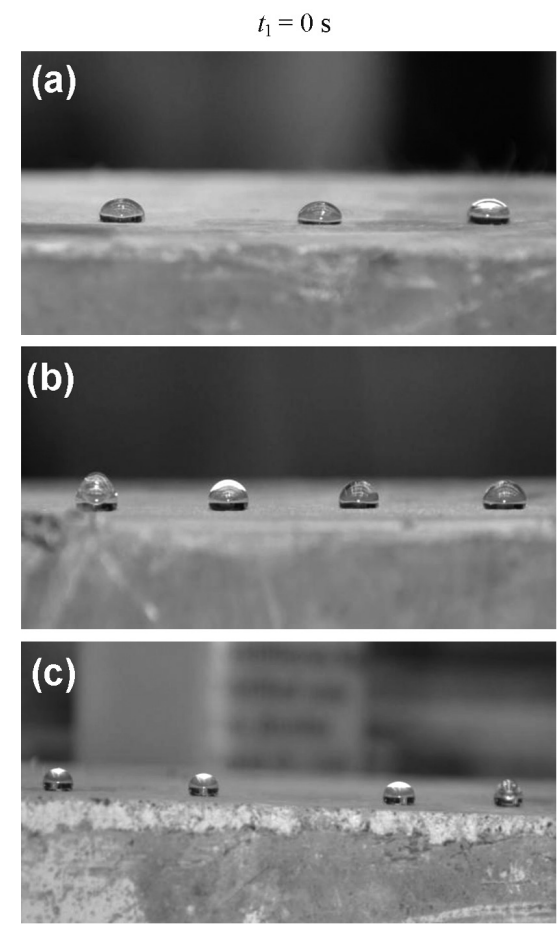

Figure 1: Standard and hydrophobized surfaces HFRHPC 1 during the examination of the contact angle of a glycerine drop: a) standard sample, b) water-soluble preparation - A, c) alkyl alkoxysilane oligomers - B

Slika 1: Navadna in hidrofobizirana površina HFRHPC 1 med preiskavo kontaktnega kota glicerinske kapljice: a) standardni vzorec, b) vodotopen preparat - A, c) alkil alkoksilan oligomeri - B

In the Owens-Wendt model, the following equations were used - for the dispersion component: ${ }^{14}$

$$
\gamma_{\mathrm{s}}^{\mathrm{d}}=\frac{\gamma_{\mathrm{g}}\left(\cos \theta_{\mathrm{g}}+1\right)-\gamma_{\mathrm{w}}\left(\cos \theta_{\mathrm{w}}+1\right) \sqrt{\gamma_{\mathrm{g}}^{\mathrm{p}} / \gamma_{\mathrm{w}}^{\mathrm{p}}}}{2\left(\sqrt{\gamma_{\mathrm{g}}^{\mathrm{d}}}-\sqrt{\gamma_{\mathrm{g}}^{\mathrm{p}} \gamma_{\mathrm{w}}^{\mathrm{d}} / \gamma_{\mathrm{w}}^{\mathrm{p}}}\right)}
$$

and for the polar component:

$$
\sqrt{\gamma_{\mathrm{S}}^{\mathrm{p}}}=\frac{\gamma_{\mathrm{w}}\left(\cos \theta_{\mathrm{w}}+1\right)-2 \sqrt{\gamma_{\mathrm{s}}^{\mathrm{d}} \gamma_{\mathrm{w}}^{\mathrm{d}}}}{2 \sqrt{\gamma_{\mathrm{w}}^{\mathrm{p}}}}
$$

where $\gamma_{\mathrm{w}}-$ the surface free energy of water, $\gamma_{\mathrm{w}}{ }^{\mathrm{d}}-$ the dispersion component of water SFE, $\gamma_{\mathrm{w}} \mathrm{p}-$ the polar component of water SFE, $\gamma_{\mathrm{g}}-$ the SFE of glycerine, $\gamma_{\mathrm{g}}{ }^{\mathrm{d}}$ - the dispersion component of glycerine SFE, $\gamma_{\mathrm{g}} \mathrm{p}-$ the polar component of glycerine SFE, $\gamma_{S}{ }^{p}-$ the polar component of SFE of the examined material, $\gamma_{S}{ }^{d}-$ the dispersion component of SFE of the examined material, $\theta_{\mathrm{g}}-$ the contact angle of glycerine, $\theta_{\mathrm{w}}-$ the contact angle of water.

The total value of SFE $\left(\gamma_{\mathrm{S}}\right)$ was determined as a sum of the polar and dispersion components:

$$
\gamma_{\mathrm{S}}=\gamma_{\mathrm{S}}^{\mathrm{p}}+\gamma_{\mathrm{S}}^{\mathrm{d}}
$$

\subsection{Scanning electron microscopy of the hydropho- bized concrete}

A qualitative analysis of the chemical compositions within the main mineral components of the standard and
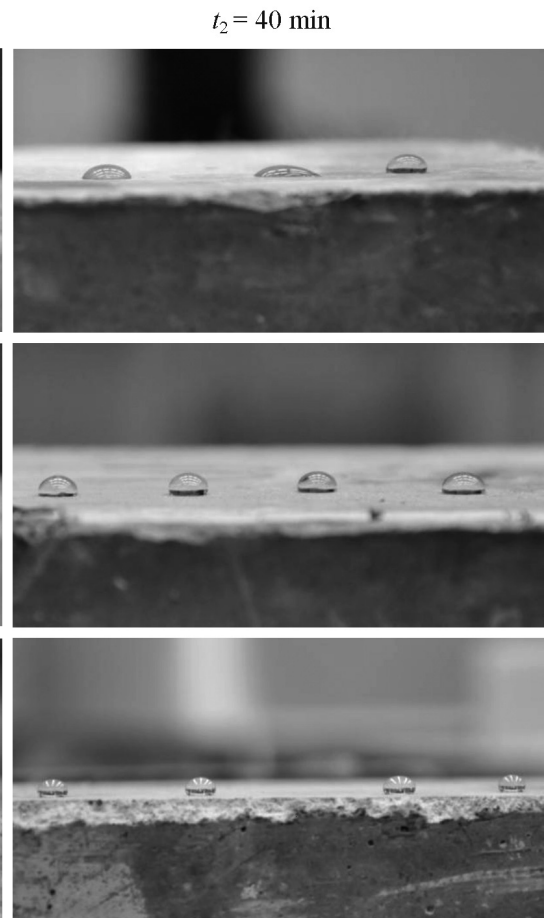
hydrophobized concretes was carried out, and the morphology and microtopography were determined using a scanning electron microscope FEI Quanta 250 FEG equipped with a chemical-composition analysis system based on energy dispersion spectroscopy (EDS). The samples were prepared in the form of thin-layer plates, on which X-ray microanalyses were performed in the field mode and the compositions of the elements were determined for the seven batches of the concretes. The sample-preparation methodology excludes the formation of the microdefects associated with the cracking of the concrete surface and hydrophobic coatings. In order to avoid the formation of other surface defects, low vacuum and beam energy were used during the SEM analysis.

\section{RESULTS AND ANALYSIS}

\subsection{Contact angle and surface free energy}

The measured contact angles of water and glycerine and the calculated values of SFE and its components are included in Tables 5 and $\mathbf{6}$, respectively.

Graphic illustrations of the results obtained are shown in Figures 2 to 4 .

Table 5: Concrete contact angles with water and glycerine Tabela 5: Kontaktni koti vode in glicerina $\mathrm{z}$ betonom

\begin{tabular}{|c|c|c|c|c|c|}
\hline \multirow{3}{*}{$\begin{array}{l}\text { Type of } \\
\text { samples }\end{array}$} & \multirow{3}{*}{$\begin{array}{c}\text { Type of } \\
\text { prepara- } \\
\text { tion }\end{array}$} & \multicolumn{4}{|c|}{ Contact angle } \\
\hline & & \multicolumn{2}{|c|}{ water $\theta_{\mathrm{w}} /{ }^{\circ}$} & \multicolumn{2}{|c|}{ glicerine $\theta_{\mathrm{g}} /^{\circ}$} \\
\hline & & $t_{1}=0$ & $t_{2}=40$ & $t_{1}=0$ & $t_{2}=40$ \\
\hline \multirow{4}{*}{ HPC 1} & Standard & 63.7 & 23.0 & 86.7 & 62.0 \\
\hline & A & 83.5 & 74.1 & 86.6 & 77.3 \\
\hline & B & 113.5 & 73.0 & 105.6 & 76.1 \\
\hline & $\mathrm{C}$ & 122.7 & 98.3 & 127.3 & 102.1 \\
\hline \multirow{4}{*}{ SFHPC } & Standard & 67.8 & 32.4 & 86.2 & 66.7 \\
\hline & A & 86.1 & 75.8 & 89.7 & 69.6 \\
\hline & $\mathrm{B}$ & 107.5 & 103.3 & 108.7 & 106.7 \\
\hline & $\mathrm{C}$ & 96.0 & 67.5 & 98.3 & 66.7 \\
\hline \multirow{4}{*}{ HFHPC 1} & Standard & 39.4 & 20.1 & 67.0 & 43.5 \\
\hline & A & 83.7 & 74.3 & 87.0 & 77.7 \\
\hline & $\mathrm{B}$ & 109.3 & 104.0 & 109.7 & 105.7 \\
\hline & $\mathrm{C}$ & 82.0 & 73.2 & 80.7 & 73.1 \\
\hline \multirow{4}{*}{ HFHPC2 } & Standard & 42.3 & 12.6 & 71.0 & 45.4 \\
\hline & $\mathrm{A}$ & 87.0 & 74.5 & 81.6 & 74.7 \\
\hline & $\mathrm{B}$ & 103.4 & 111.6 & 106.3 & 104.1 \\
\hline & $\mathrm{C}$ & 78.0 & 62.1 & 77.0 & 64.3 \\
\hline \multirow{4}{*}{ HFHPC3 } & Standard & 55.5 & 26.0 & 73.4 & 47.8 \\
\hline & $\mathrm{A}$ & 92.8 & 75.8 & 94.7 & 78.4 \\
\hline & B & 113.4 & 103.3 & 106.8 & 103.6 \\
\hline & $\mathrm{C}$ & 78.9 & 67.7 & 80.0 & 70.7 \\
\hline \multirow{4}{*}{ PFHPC } & Standard & 47.1 & 14.2 & 73.3 & 54.0 \\
\hline & A & 100.7 & 78.3 & 103.3 & 82.1 \\
\hline & B & 105.6 & 95.5 & 110.0 & 97.0 \\
\hline & $\mathrm{C}$ & 101.8 & 83.7 & 94.5 & 85.7 \\
\hline \multirow{4}{*}{ HPC2 } & Standard & 53.4 & 10.1 & 78.1 & 56.8 \\
\hline & $\mathrm{A}$ & 102.5 & 83.4 & 100.4 & 79.3 \\
\hline & B & 116.3 & 100.2 & 122.3 & 94.3 \\
\hline & $\mathrm{C}$ & 116.1 & 100.5 & 119.8 & 105.6 \\
\hline
\end{tabular}

Table 6: SFE and its components for hydrophobized and standard concretes

Tabela 6: SFE in njene komponente pri hidrofobiziranih in standardnih betonih

\begin{tabular}{|c|c|c|c|c|c|c|c|}
\hline \multirow{3}{*}{$\begin{array}{c}\text { Type } \\
\text { of } \\
\text { sample }\end{array}$} & \multirow{3}{*}{$\begin{array}{c}\text { Type of } \\
\text { prepara- } \\
\text { tion }\end{array}$} & \multicolumn{4}{|c|}{ SFE component } & \multirow{2}{*}{\multicolumn{2}{|c|}{$\begin{array}{c}\text { Total SFE } \\
\gamma_{\mathrm{S}} /\left(\mathrm{mJ} / \mathrm{m}^{2}\right)\end{array}$}} \\
\hline & & \multicolumn{2}{|c|}{$\begin{array}{c}\text { Dispersive } \\
\gamma_{\mathrm{S}}^{\mathrm{d}} /\left(\mathrm{mJ} / \mathrm{m}^{2}\right)\end{array}$} & \multicolumn{2}{|c|}{$\begin{array}{c}\text { Polar } \\
\mathrm{s}^{\mathrm{p}} /\left(\mathrm{mJ} / \mathrm{m}^{2}\right)\end{array}$} & & \\
\hline & & $t_{1}=0$ & $t_{2}=40$ & $t_{1}=0$ & $t_{2}=40$ & $t_{1}=0$ & $t_{2}=40$ \\
\hline \multirow{4}{*}{ HPC1 } & Standard & 1313.9 & 1873.8 & 266.9 & 342.5 & 1580.8 & 2216.3 \\
\hline & A & 72.5 & 83.6 & 0.01 & 0.27 & 72.51 & 83.87 \\
\hline & $\mathrm{B}$ & 65.5 & 82.0 & 4.95 & 0.45 & 70.45 & 82.45 \\
\hline & $\mathrm{C}$ & 48.9 & 71.4 & 4.96 & 1.35 & 53.86 & 72.75 \\
\hline \multirow{4}{*}{ SFHPC } & Standard & 905.8 & 1833.5 & 160.04 & 345.60 & 1065.84 & 2179.1 \\
\hline & A & 82.0 & 12.5 & 0.23 & 16.30 & 82.23 & 28.80 \\
\hline & $\mathrm{B}$ & 17.9 & 56.1 & 0.63 & 0.94 & 18.53 & 57.04 \\
\hline & $\mathrm{C}$ & 43.2 & 17.7 & 0.07 & 18.48 & 43.27 & 36.18 \\
\hline \multirow{4}{*}{$\mid \begin{array}{c}\text { HFHPC } \\
1\end{array}$} & Standard & 1385.0 & 595.6 & 233.8 & 36 & 1618.8 & 632.45 \\
\hline & $\mathrm{A}$ & 77.1 & 88.5 & 0.01 & 0.11 & 77.11 & 88.61 \\
\hline & B & 9.4 & 26.6 & 2.00 & & & \\
\hline & $\mathrm{C}$ & 6.3 & 22.5 & 17.30 & 12.03 & 23.60 & 34.53 \\
\hline \multirow{4}{*}{$\begin{array}{c}\text { HFHPC } \\
2\end{array}$} & Standard & 1572.1 & 860.8 & 290.79 & 82.96 & 1862.89 & 943.79 \\
\hline & A & 12.3 & 25.6 & 9.44 & 9.91 & 21.74 & 35.51 \\
\hline & $\mathrm{B}$ & 46.4 & 57.0 & 0.29 & 2.95 & 46.69 & 59.95 \\
\hline & $\mathrm{C}$ & 10.3 & 68.7 & 16.47 & 5 & 26.77 & 72.95 \\
\hline \multirow{4}{*}{$\mid \begin{array}{c}\mathrm{HFHPC} \\
3\end{array}$} & Standard & 803.5 & 641.1 & 111.2 & 47.24 & 914.70 & 688.34 \\
\hline & A & 39.0 & 68.0 & 0.59 & 0.92 & 39.59 & 68.92 \\
\hline & B & 40.4 & 11.0 & 1.17 & 3.08 & 41.57 & 14.08 \\
\hline & $\mathrm{C}$ & 36.2 & 83.3 & 4.59 & 1.13 & 40.79 & 84.46 \\
\hline \multirow{4}{*}{ PFHPC } & Standard & 1426.9 & 1438.8 & 260.06 & 217.8 & 1686.96 & 1656.6 \\
\hline & A & 43.9 & 95.4 & 0.03 & 0.07 & 43.93 & 95.47 \\
\hline & B & 74.0 & 30.2 & 3.60 & 1.03 & 77.60 & 31.23 \\
\hline & $\mathrm{C}$ & 49.8 & 48.6 & 0.31 & 1.20 & 50.11 & 49.80 \\
\hline \multirow{4}{*}{ HPC2 } & Standard & 841.1 & 1798.1 & 127.99 & 309.91 & 1631.50 & 2108.0 \\
\hline & A & 0.1 & 2.0 & 15.45 & 22.55 & 15.46 & 24.55 \\
\hline & B & 88.3 & 25.4 & 10.92 & 0.81 & 99.22 & 26.21 \\
\hline & $\mathrm{C}$ & 44.5 & 100.3 & 2.27 & 5.66 & 46.77 & 105.96 \\
\hline
\end{tabular}

\subsection{Scanning electron microscopy of the hydropho- bized concrete}

SEM microscopic analyses were performed to verify the distribution and effectiveness of hydrophobic coatings $\mathrm{A}, \mathrm{B}, \mathrm{C}$ in the pores of the concrete. For the analyses, the HFHPC1 concrete was adopted, for which

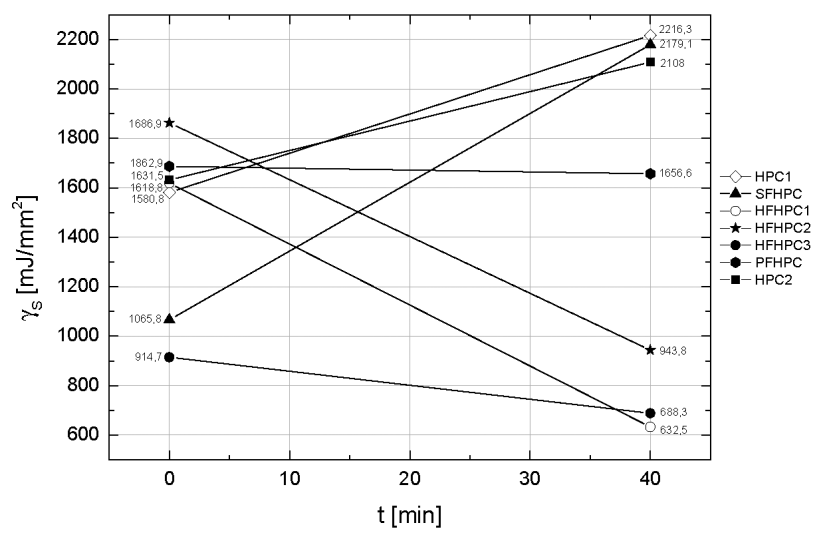

Figure 2: Total values of SFE of standard concretes at the beginning of the examination and after $40 \mathrm{~min}$

Slika 2: Skupna vrednost SFE standardnih betonov na začetku preizkusa in po $40 \mathrm{~min}$ 


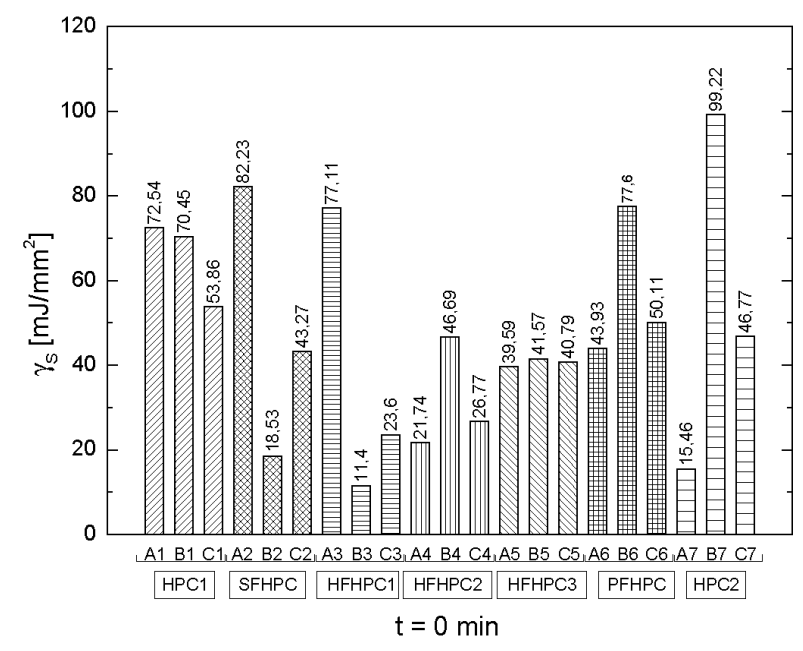

Figure 3: Total values of SFE of hydrophobized concretes at the beginning of the examination $(t=0)$

Slika 3: Skupna vrednost SFE pri hidrofobiziranih betonih na začetku preizkusa $(t=0)$

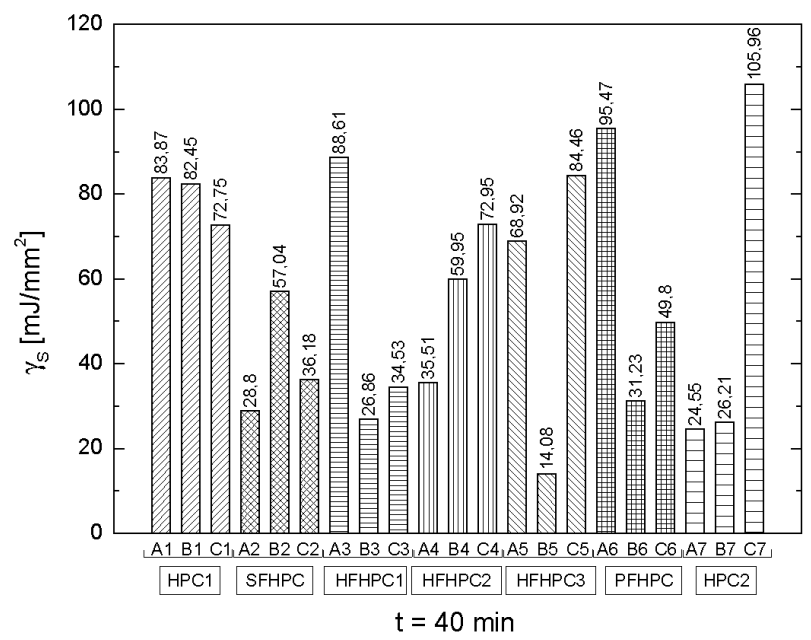

Figure 4: Total values of SFE of hydrophobized concretes after 40 $\min$

Slika 4: Skupna vrednost SFE pri hidrofobiziranih betonih po $40 \mathrm{~min}$

the best hydrophobic properties of the coatings were obtained. Table 7 shows the analyses of the chemical
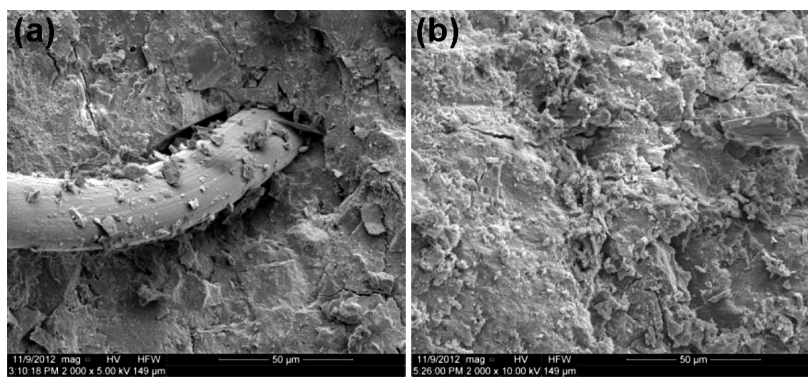

Figure 5: Microstructures of HFHPC1 and HPC2 concretes prior to hydrophobization, SEM

Slika 5: Mikrostruktura HFHPC1 in HPC2 betona pred hidrofobizacijo, SEM

compositions in the field mode for standard HFHPC1 and hydrophobized concretes using preparations $\mathrm{A}, \mathrm{B}$ and $\mathrm{C}$, performed on the basis of energy dispersion spectroscopy (the results from the entire area of the study).

Table 7: Chemical compositions of standard and hydrophobized HFHPC 1

Tabela 7: Kemijska sestava standardnih in hidrofobiziranih HFHPC1

\begin{tabular}{|c|c|c|c|c|c|c|}
\hline \multirow{2}{*}{ HFHPC1 } & \multicolumn{7}{|c|}{ Component, $w / \%$} \\
\cline { 2 - 7 } & $\mathrm{Na}_{2} \mathrm{O}$ & $\mathrm{MgO}$ & $\mathrm{Al}_{2} \mathrm{O}_{5}$ & $\mathrm{SiO}_{2}$ & $\mathrm{~K}_{2} \mathrm{O}$ & $\mathrm{CaO}$ \\
\hline Standard & 0.98 & 0.87 & 0.63 & 22.66 & - & 72.39 \\
\hline $\mathrm{A}$ & 0.75 & 1.31 & 1.60 & 68.20 & 25.38 & 2.29 \\
\hline $\mathrm{B}$ & 0.49 & 2.07 & 1.81 & 13.46 & - & 82.18 \\
\hline $\mathrm{C}$ & 0.69 & 1.57 & 0.72 & 29.34 & - & 67.69 \\
\hline
\end{tabular}

The microstructures of HFHPC1 and HPC2 are shown in Figure 5.

Distribution of polysiloxane gel in the structure of hydrophobized HFHPC1 is shown in Figure 6.

\section{DISCUSSION}

\subsection{Contact angle and surface free energy}

When analyzing the examination results presented in Tables 5 and 6, it can be noticed that the values of the contact angles and the surface free energy depend on the
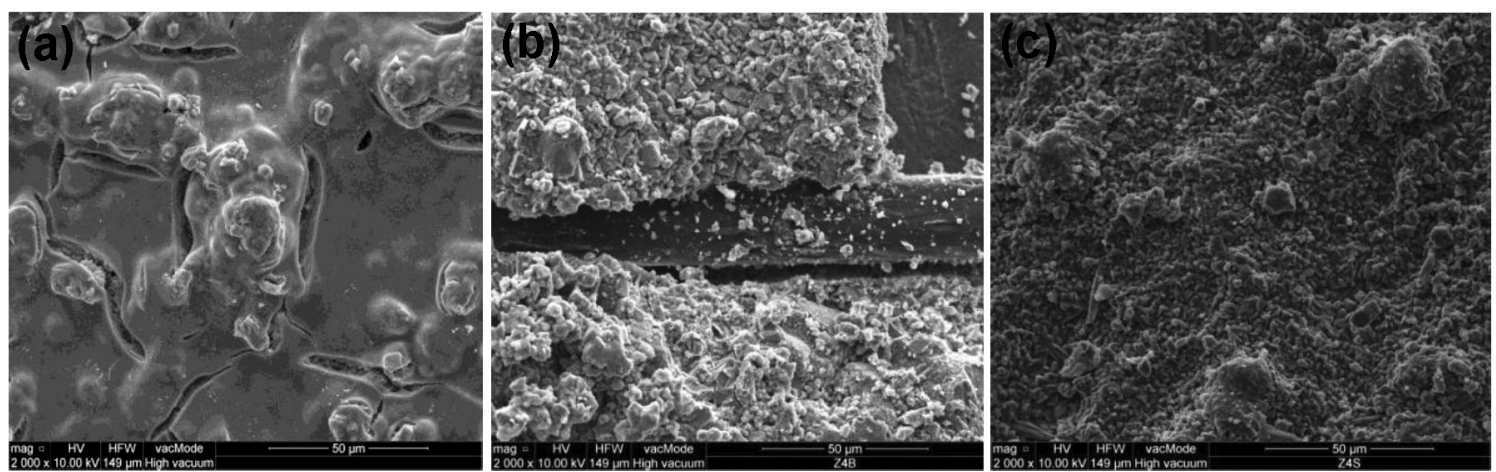

Figure 6: Organosilicon compounds in the microstructure of HFHPC1: a) water-soluble preparation - A, b) alkyl alkoxysilane oligomers - B, c) methylosilicone resin - C, SEM

Slika 6: Organosilikonske spojine v mikrostrukturi HFHPC1: a) vodotopen preparat - A, b) alkil alkilosilan oligomer - B, c) metilsilikonska smola - C, SEM 
type of hydrophobic preparations and also on the type of concrete.

The results of the contact-angle measurements proved that in most cases the contact angle of glycerine $\left(\theta_{\mathrm{g}}\right)$ is higher than the contact angle of water $\left(\theta_{\mathrm{w}}\right)$, and it decreases in the course of time. The contact angles of water obtained for the standard samples at $t_{1}=0$ range from $\theta_{\mathrm{w}}=39.4^{\circ}$ for HFHPC 1 to $\theta_{\mathrm{w}}=67.8^{\circ}$ for SFHPC; at $t_{2}=40 \mathrm{~min}$, they range from $\theta_{\mathrm{w}}=10.1^{\circ}$ for HPC2 to $\theta_{\mathrm{w}}=32.4^{\circ}$ for SFHPC. In the case of the standard samples, the contact angles of glycerine are higher than the contact angles of water (67.0 for HFHPC1 and 86.7 for HPC1 at $t_{1}=0 ; 29.9$ for HFHPC2 and 62.0 for HPC1 at $t_{2}=40 \mathrm{~min}$ ).

The highest contact angles of water, $\theta_{\mathrm{w}}=122.7^{\circ}$, and glycerine, $\theta_{\mathrm{g}}=127.3^{\circ}$, at $t_{1}=0$ were obtained for methylosilicone resin (C) used for HPC1. In all the other cases, the largest contact angle was obtained with alkyl alkoxysilane (B) and it ranged from $103.4^{\circ}$ to $116.3^{\circ}$ $\left(t_{1}=0\right)$ and from $73.0^{\circ}$ to $111.6^{\circ}\left(t_{1}=40 \mathrm{~min}\right)$, which proved that a very good surface hydrophobicity was obtained with this preparation.

For the non-hydrophobized concretes, the value of the surface free energy is the highest and it amounts to $\gamma_{\mathrm{S}}$ $=914.69 \mathrm{~mJ} / \mathrm{m}^{2}$ for HFHPC 3 and $\gamma_{\mathrm{S}}=1862.93 \mathrm{~mJ} / \mathrm{m}^{2}$ for HFHPC2. With respect to the non-hydrophobized concretes, the SFE value is up to 142 times higher for the concrete with granite and up to 105 times higher for the concrete with granodiorite aggregate than in the case of the impregnated surfaces. The lowest value of SFE, $\gamma_{\mathrm{S}}=$ $11.40 \mathrm{~mJ} / \mathrm{m}^{2}$ (the weakest adhesion properties), was obtained for the HFHPC1 concrete hydrophobized with alkyl alkoxysilane in the organic solvent (B). In the cases of the PFHPC and HPC2 concretes with granite aggregate, preparation B showed much lower hydrophobic properties, since the value of SFE was higher by $27.55-83.77 \mathrm{~mJ} / \mathrm{m}^{2}$ than those of the other preparations. The concretes with granite aggregate obtained the highest hydrophobicity using the water-based solution of methylosilicone resin in potassium hydroxide $\left(\gamma_{\mathrm{s}}=\right.$ $15.46-43.93 \mathrm{~mJ} / \mathrm{m}^{2}$ ).

Furthermore, it can be noticed that in all the cases the SFE dispersive component $\left(\gamma_{\mathrm{S}}{ }^{\mathrm{d}}\right)$ constitutes a far larger share in the total SFE value $\left(\gamma_{S}\right)$ than the polar component $\left(\gamma_{S^{p}}\right)$.

Considering the variations in time it was observed that in the course of time (after 40 minutes) the total SFE value decreased in the case of the concretes containing steel and polypropylene fibers with both granodiorite and granite aggregates. In the other concretes without fibers, the SFE value decreased after $40 \mathrm{~min}$, proving a decrease in the hydrophobicity.

\subsection{Scanning electron microscopy of the hydropho- bized concrete}

A uniformly distributed silicon coating is formed in the microstructure of the concrete due to the water- soluble preparation (A); however, it is too thick and shows numerous cracks. Analyzing the microstructure of the coating obtained from preparation A, it can be concluded that it creates the sealing for the fine subsurface pores of the concrete, resulting in a decrease in the water-vapor permeability of the concrete. The coating that is too thick does not provide an adequate adhesion to the concrete minerals, making the hydrophobization less effective. As a result of frost or chemical corrosion the coating will be damaged within a very short period of time.

The methylosilicone-resin coating $(\mathrm{C})$ is of a homogeneous nature, as it is made from fine particles and does not create the sealing for the HFHPC1 structure. This ensures a good efficiency of the impregnation and does not disturb the diffusion of gases and vapors.

The alkyl-alkoxysilane-oligomer preparation (B), based on an organic solvent, is characterized by a finepore structure composed of even smaller particles than the macromolecular resin (C). Microscopic observations proved that the coating was uniformly distributed and it did not show any defects.

\section{CONCLUSION}

The measurement of the contact angle is one of the methods for monitoring the changes in the wettability of hydrophobized building materials.

The use of various preparations results in obtaining different wetting and adhesion properties of HFHPC, determined by the surface free energy. The SFE value decreases significantly on a hydrophobized surface, in particular when using a small molecule oligomer for the concretes with granodiorite aggregate or a water-based solution of methylosilicone resin in the potassium hydroxide for the concretes with granite aggregate. As proved, this may result from a more effective hydrophobization, due to macromolecular resins, of the materials characterized by the pores of bigger diameters like granite-aggregate-based concretes. Adding polypropylene and steel fibers contributes to an increased hydrophobicity in the course of time.

The application of organosilicon compounds in the near-concrete surface area results in a reduction in the SFE and surface tension of the concrete, depending on the chemical composition of the preparation. This causes a reduced penetration of the corrosive substances into the concrete structure, thus affecting its durability.

Evenly distributed silica gel is formed in the fine pores of the high-strength concrete by organic-solventbased preparations $\mathrm{B}$ and $\mathrm{C}$. This coating is characterized by a fine-pore microstructure; it shows an adequate adhesion to the concrete surface. Such properties of silicone resin ensure a good vapor permeability and effective hydrophobization. 


\section{REFERENCES}

${ }^{1}$ P. Richard, M. Cheyrezy, Composition of reactive powder concretes, Cement Concrete Research, 25 (1995) 7, 1501-1511, doi:10.1016/ 0008-8846(95)00144-2

${ }^{2}$ J. S. Barnett, J. Lataste, T. Parry, S. G. Millard, M. N. Soutsos, Assessment of fibre orientation in ultra-high performance fibre reinforced concrete and its effect on flexural strength, Materials and Structures, 43 (2010), 1009-1023, doi:10.1617/s11527-009-9562-3

${ }^{3}$ A. M. Brandt, Fibre-reinforced cement-based (FRC) composites after over 40 years of development in building and civil engineering, Composite Structures, 86 (2008) 1-3, 3-9, doi:10.1016/j.compstruct. 2008.03.006

${ }^{4}$ Y. G. Zhu, S. C. Kou, C. S. Poon, J. G. Dai, Q. Y. Li, Influence of silane-based water repellent on the durability properties of recycled aggregate concrete, Cement and Concrete Composites, 35 (2013), 32-38, doi:10.1016/j.cemconcomp.2012.08.008

${ }^{5}$ A. Johansson, M. Janz, J. Silfwerbrand, J. Trägärdh, Penetration depth for water repellent agents in concrete as a function of humidity, porosity and time, International Journal Restoration of Buildings and Monuments, 13 (2007), 3-16, doi:10.1515/rbm-2007-6102

${ }^{6} \mathrm{~F}$. Tittarelli, Oxygen diffusion through hydrophobic cement-based materials, Cement and Concrete Research, 39 (2009), 924-928, doi:10.1016/j.cemconres.2008.06.009

${ }^{7}$ B. Felekoğlu, A method for improving the early strength of pumice concrete blocks by using alkyl alkoxy silane (AAS), Construction and Building Materials, 28 (2012), 305-310, doi:10.1016/ j.conbuildmat.2011.07.026

${ }^{8}$ R. Z. Homod, K. S. M. Sahari, Energy savings by smart utilization of mechanical and natural ventilation for hybrid residential building model in passive climate, Energy and Buildings, 60 (2013), 310-329, doi:10.1016/j.enbuild.2012.10.034

${ }^{9}$ K. Sobolev, K. Batrakov, Effect of a Polyethylhydrosiloxane Admixture on the Durability of Concrete with Supplementary Cementitious Materials, Journal of Materials in Civil Engineering, 19 (2007) 10, 809-819, doi:10.1061/(ASCE)0899-1561(2007)19: 10(809)

${ }^{10}$ I. Flores-Vivian, V. Hejazi, M. I. Kozhukhova, M. Nosonovsky, K. Sobolev, Self-Assembling Particle-Siloxane Coatings for Superhydrophobic Concrete, ACS Applied Materials \& Interface, 24 (2013) 5, 13284-13294, doi:10.1021/am404272v

${ }^{11}$ A. M. Brandt, Present trends in the mechanics of cement based fibre reinforced composites, Construction and Building Materials, 1 (1987) 1, 28-39, doi:10.1016/0950-0618(87)90057-2

${ }^{12}$ L. Czarnecki, Sustainable Concrete; Is Nanotechnology the Future of Concrete Polymer Composites?, Advanced Materials Research, 687 (2013), 3-11, doi:10.4028/www.scientific.net/AMR.687.3

${ }^{13}$ L. Czarnecki, Polymer concretes, Cement Lime Concrete, 15 (2010) 2, 63-85 (in Polish)

${ }^{14}$ A. Rudawska, Selected issues on establishing adhesion bonds - homogeneous and hybrid, Monographs, Lublin University of Technology, Lublin 2013

${ }^{15}$ R. Sikora, Processing of macromolecular materials, Wydawnictwo Edukacyjne, Warsaw 1995

${ }^{16}$ PN-EN 828:2000 Adhesives, Determining wettability by means of measuring the contact angle and critical surface tension of solid, 2000
${ }^{17}$ E. Lugscheider, K. Bobin, The influence on surface free energy of PVD-coatings, Surface Coatings Technology, 142-144 (2001), 755-760, doi:10.1016/S0257-8972(01)01315-9

${ }^{18}$ G. Cappelletti, S. Ardizzone, D. Meroni, G. Soliveri, M. Ceotto, C. Biaggi, M. Benaglia, L. Raimondi, Wettability of bare and fluorinated silanes: a combined approach based on surface free energy evaluations and dipole moment calculations, Journal of Colloid and Interface Science, 389 (2013), 284-291, doi:10.1016/j.jcis.2012.09. 008

${ }^{19}$ M. Żenkiewicz, Adhesion and modifying the surface layer of macromolecular materials, WNT, Warszaw 2000

${ }^{20}$ D. Sotiropoulou, S. Agathopoulos, P. Niklopoulos, Work of adhesion in ceramic oxide/liquid metal system, Journal of Adhesion Science and Technology, 10 (1996), 989-998, doi:10.1163/ 156856196X00058

${ }^{21}$ A. Baldan, Adhesion phenomena in bonded joints, International Journal of Adhesion and Adhesives, 38 (2012), 95-116, doi:10.1016/ j.ijadhadh.2012.04.007

${ }^{22}$ E. Chibowski, F. Gonzalez-Caballero, Interpretation of contact angle hysteresis, Journal of Adhesion Science and Technology, 7 (1993), 1195-1209, doi:10.1163/156856193X00051

${ }^{23}$ C. W. Extrand, A thermodynamic model for contacts angle hysteresis, Journal of Colloid and Interface Science, 27 (1998), 11-19, doi:10.1006/jcis.1998.5743

${ }^{24}$ S. Vedantam, M. V. Panchagnula, Constitutive modeling of contact angle hysteresis, Journal of Colloid and Interface Science, 321 (2008), 393-400, doi:10.1016/j.jcis.2008.01.056

${ }^{25} \mathrm{M}$. Zielecka, Methods of contact angle measurement as a tool for characterization of wettability of polymers, Polymers, 49 (2004), 327-332

${ }^{26}$ M. Żenkiewicz, P. Rytlewski, J. Czupryńska, J. Polański, T. Karasiewicz, W. Engelgard, Contact angle and surface free energy of electron-beam irradiated polymer composites, Polymers, 53 (2008), 446-451

${ }^{27}$ J. Shang, M. Flury, J. B. Harsh, R. L. Zollars, Comparison of different methods to measure contact angles of soil colloids, Journal of Colloid and Interface Science, 328 (2008), 299-307, doi:10.1016/ j.jcis.2008.09.039

${ }^{28}$ U. Stachewicz, S. Li, E. Bilotti, A. H. Barber, Dependence of surface free energy on molecular orientation in polymer films, Applied Physics Letters, 100 (2012), 094104, doi:10.1063/1.3691186

${ }^{29}$ M. Żenkiewicz, Comparative study on the surface free energy of a solid calculated by different methods, Polymer Testing, 26 (2007) 1, 14-19, doi:10.1016/j.polymertesting.2006.08.005

${ }^{30} \mathrm{~S}$. Ahadian, M. Mohseni, S. Morawian, Ranking proposed models for attaining surface free energy of powders using contact angle measurements, International Journal of Adhesion and Adhesives, 29 (2009), 458-469, doi:10.1016/j.ijadhadh.2008.09.004

${ }^{31}$ A. Rudawska, J. Kuczmaszewski, Galvanized sheet bonding, University Publishing, Lublin University of Technology, Lublin 2005

${ }^{32}$ A. Rudawska, E. Jacniacka, Analysis of Determining Surface Free Energy Uncertainty with the Owens-Wendt Method, International Journal of Adhesion and Adhesives, 29 (2009), 451-457, doi:10.1016/j.ijadhadh.2008.09.00

${ }^{33}$ D. Rossi, E. Mioni, M. Zancato, A. Bettero, S. Rossi, Development of a tensiometric model for surface energy characterization of raw coffee beans, Journal of Food Engineering, 112 (2012), 352-357, doi:10.1016/j.jfoodeng.2012.04.006 